\title{
Extracorporeal Membrane Oxygenation (ECMO) for Pediatric Respiratory Failure due to Respiratory Syncytial Virus Infection
}

\section{Otto M González-Pardo* and Gabriel Cassalett-Bustillo}

Pediatric Intensivist, Shaio Clinic Foundation, ECMO group, Bogotá, Colombia, USA

${ }^{*}$ Corresponding author: Otto M González-Pardo, Pediatric Intensivist, Shaio Clinic Foundation, ECMO group, Bogotá, Colombia, USA Tel: 5713174278878, Email: uciotto@yahoo.com

Received date: May 07, 2016; Accepted date: June 03, 2016; Published date: June 08, 2016

Citation: González-Pardo OM, Cassalett-Bustillo G (2016) Extracorporeal Membrane Oxygenation (ECMO) for Pediatric Respiratory Failure due to Respiratory Syncytial Virus Infection. Pediatric Infect Dis 1: 16. doi: 10.21767/2573-0282.100016

Copyright: (c) 2016 Otto M González-Pardo, et al. This is an open-access article distributed under the terms of the Creative Commons Attribution License, which permits unrestricted use, distribution, and reproduction in any medium, provided the original author and source are credited.

\section{Short Commentary}

Extracorporeal membrane oxygenation (ECMO) is a useful therapeutic alternative in the management of refractory respiratory failure in children. ECMO is a therapy that since 1985 has shown to have a survival rate of $53 \%$ in this group, with survival rates in recent years of $63 \%$, especially if the etiology is respiratory syncytial virus.

Bronchiolitis due to respiratory syncytial virus has an aggressive course in the first five to seven days leading in some cases to hypoxemic refractory respiratory failure.

Extracorporeal membrane oxygenation is an alternative therapy for pediatric respiratory failure when it has a refractory course (persistent hypoxemia or severe hypercapnia despite conventional mechanical ventilation or high frequency ventilation and nitric oxide).

It has been previously demonstrated that hypoxemia is not related to mortality in patients with acute respiratory distress, but some ventilatory mechanic parameters have been associated with poor outcomes and are being used as an indication to start extracorporeal membrane oxygenation.

The initiation of therapy is recommended in the following conditions:

- Oxygenation index greater than 40 (fraction of inspired oxygen $x$ mean airway pressure)/Arterial pressure of oxygen) has been associated with high mortality up to $80 \%$.

- Static lung compliance (Tidal volume/(Plateau pressure PEEP)) of less than $0.5 \mathrm{~mL} / \mathrm{cm} \mathrm{H}_{2} \mathrm{O} / \mathrm{kg}$

- Intrapulmonary shunt ((Alveolar oxygen contentarterial oxygen content)/(alveolar oxygen content - venous oxygen content)) greater than $50 \%$ with an $\mathrm{FiO}_{2}$ greater than 0.6

- Hypercapnia with a pH less than 7.0 with a peak inspiratory pressure greater than $40 \mathrm{~cm} \mathrm{H}_{2} \mathrm{O}$ (Patients cannulated for ECMO with a $\mathrm{pH}$ less than 7.29 , have a greater risk to die [1].

Recovery of lung function in these patients usually takes two to three weeks, during this period the extracorporeal membrane oxygenation intended to prevent lung injury caused by the mechanical ventilation.
Respiratory syncytial virus is the main causative agent of acute bronchiolitis in pediatric patients ( 20 to $40 \%$ of cases); it is isolated in $75 \%$ of hospitalizations in patients younger than 2 years [2].

Bacterial pneumonia and viral bronchiolitis are the most frequent indications for initiation of respiratory extracorporeal membrane oxygenation in children, with survival rates increasing form 52\% in 1994, achieving a 63\% survival in 2011, particularly when the etiology is respiratory syncytial virus $[3,4]$.

In Colombia acute respiratory infection is the second leading cause of mortality in children under 5 years [5-7].

\section{References}

1. Dalton H, Fortenberry JD, Frenckner B (2012) ECMO for Pediatric Respiratory Failure. In: Cooke C, editor. ECMO Extracorporeal Cardiopulmonary Support in Critical Care. 4th edn. Ann Harbor (Michigan): Extracorporeal Life Support Organization pp 265-287.

2. Sánchez J, Alustiza J, Arranz L, Guiu M (2008) Guía consensuada para el manejo de la bronquiolitis aguda. Boletín $\mathrm{S}$ Vasco-Nav Pediatr 40: 16-20.

3. Zabrocki LA, Brogan TV, Statler KD, Poss WB, Rollins MD, et al (2011) Extracorporeal membrane oxygenation for pediatric respiratory failure: Survival and predictors of mortality. Crit Care Med 39: 364-370.

4. Dalton H, Duncan J (2015) Extracorporeal support in children with pediatric acute respiratory distress syndrome: proceedings from the pediatric acute lung injury consensus conference. Pediatr Crit Care Med 16: S111-7.

5. Rodríguez DA, Rodríguez-Martínez CE, Cárdenas AC, Quilaguy IE, Mayorga LY, et al. (2014) Predictors of severity and mortality in children hospitalized with respiratory syncytial virus infection in a tropical region. Pediatr Pulmonol 49: 269-76.

6. Harthan A, Buckley W, Heger M, Fortuna R, Mays K (2014) Medication Adsorption into Contemporary Extracorporeal Membrane Oxygenator Circuits. J Pediatr Pharmacol Ther 19: 288-295.

7. De Mol A, Liem K, Van Heijst A (2013) Cerebral Aspects of Neonatal Extracorporeal Membrane Oxygenation: A Review. Neonatology 104: 95-103. 
